\title{
Uludağ Üniversitesi Sağlık Hizmetleri Meslek Yüksekokulu Öğrencilerinin Problem Çözme Becerlileri İle Empatik Becerilerinin Karşılaştırılması*
}

\author{
Gökhan AYTEKIN ${ }^{1}$, Senem TURAN ÖZDEMIR ${ }^{2}$, Pelin EDIZ ${ }^{3}$, Fikret CEYLAN ${ }^{4}$ \\ 1,2,3,4 Uludağ Üniversitesi, Sağlık Hizmetleri Meslek Yüksekokulu, Bursa, Türkiye
}

\section{Giriş}

Sorun çözme becerisi, kişiyi çözüme götürecek bilgilerin kazanılması ve bu bilgileri kullanıma hazır olacak şekilde birleştirerek bir sorunun çözümüne uygulayabilme düzeyidir. Empati ise,"kendini kaybetmeksizin karşıdaki kişinin iç dünyasında olanları kendisi yaşıyormuş gibi hissederek anlamak" olarak tanımlamaktadır. Bilgi toplumunun küreselleşmiş dünyasında, başarılı bir birey olabilmek için, salt belli bir düzeyde mesleki ve teknik bilgilere sahip olmak artık yeterli olmamaktadır. Bireyden bilgiye ulaşma, bilgiyi çözümleme, sürekli olarak bilgisini yenileyebilme kapasitesine ulaşmış olması, problem çözme becerilerinin ve empatik becerilerinin yüksek olması beklenmektedir. Bu nedenle günümüz toplumu bireylerin yaratıcı, eleştirel, analitik düşünebilen ve karşılaştığı farklı sorunlara etkili çözümler üretebilen özellikte olmasını gerekli kılmaktadır.

Özellikle yardımcı sağlık personelinin problem çözme becerisi ve empatik beceri düzeylerinin yüksek olması sağlık hizmeti sürecinin başarılı bir şekilde uygulanmasını sağlayarak sağlık hizmeti kalitesinin yükseltilmesinde önemli bir rol oynayabilir. Bu nedenle yüksek kalitede sağlık hizmetleri verilebilmesi için; yardımcı sağlık personeli olarak çalışacak olan öğrencilerin empati ve problem çözme becerilerinin aldıkları mesleki eğitimin etkisi ile gelişmesi beklenir.

Bu çalışmada Uludağ Üniversitesi Sağlık Hizmetleri Meslek Yüksekokulu Anestezi Teknikerliği, Tibbi Laboratuvar, Radyoloji ve Tibbi Dokümantasyon ve Sekreterlik programlarında okuyan 1. ve 2. sınıf öğrencilerinin problem çözme becerileri (PÇB) ile empatik becerilerini (EB) belirlemek, karşılaştırmak ve aldıkları mesleki eğitimin bu becerilere etkisini saptamak amaçlanmıştır.

\section{Gereç ve Yöntem}

Araştırmaya 139'u kız, 28'i erkek olmak üzere 167 öğrenci katıldı. Veriler öğrencilerin sosyo demografik özelliklerini belirlemeye yönelik 16 soru, kişisel özelliklerini belirlemeye yönelik 29 sorudan oluşan toplam 45 soruluk bir anket formu; standart problem çözme ölçeği ve empati ölçeği kullanılarak elde edildi.

Problem Çözme Ölçeği; Heppner ve Peterson tarafından 1982 y1lında geliştirmiş ve Taylan tarafından 1990 yılında güvenirlik ve geçerlilik çalışması yapılarak Türkçe'ye uyarlandı (Taylan 1997). Ölçek 6 puanlı, likert tipinde, 35 maddeden oluşturuldu. Seçeneklerden 1 tamamen katılımı, 6 ise tamamen katılmamayı gösterir. Bazı maddeler olumsuz olarak ifade edilmelerinden dolayı ters çevrilerek puanlanır $(1,2,3,4,11,13,14,15,17,21,25,26,30,34)$. Bazı maddeler ise puanlama dış1 tutulur $(9,22,29)$. Ölçekten alınacak en düşük puan 32, en yüksek puan ise 192 'dir. Düşük puan etkili ve başarılı problem çözme ile ilgili davranış ve tutumu, yüksek puan ise problemler karşısında etkili çözümler bulamamayı belirtir. Ölçeğin cevaplama süresi 15 dakikadır.

Empatik Beceri Ölçeği Formu'nda altı farklı sorun yer almaktadır. Her bir sorunun altında böyle bir sorunu dile getiren kişiye verilebilecek on iki çeşit empatik tepki sıralanmıştır. Deneklerden bu

\footnotetext{
*Bu çalışma Van Yüzüncü Yıl üniversitesi tarafından 18-22 Haziran 2008 tarihleri arasında düzenlenen 3. Ulusal Sağlık Hizmetleri Meslek Yüksekokulları Sempozyumu'nda Poster bildiri olarak sunulmuştur.
} 
tepkilerden beğendikleri dört tanesini seçmeleri istenir (on iki tepkiden bir tanesi tesadüfi cevaplayanları belirlemek amaciyla konulmuş olan, soruna ilgisiz tepkidir). Bireylerin her bir probleme ilişkin seçtikleri 4 cümlenin (toplam 24) likert türü ölçek üzerinden alacakları puanlar dikkate alınmaktadır. Ölçekten alınan yüksek puan empatik becerinin yüksek olduğunu gösterir. $\mathrm{Bu}$ form Dökmen (2000) tarafından 1988'de geliştirilmiştir.

Veriler toplandıktan sonra uygulanan anket formu ve ölçeklerden alınan puanlar elde kodlanmış ve SPSS V 13.0 paket programında değerlendirilmiştir. İstatistiksel analizlerde Bir Yönlü Varyans Analizi (ANOVA), Student T Testi ve Pearson Korelasyon Metodu Kullanılmıştır.

\section{Bulgular}

Öğrencilerin Empati becerisi ve Problem Çözme becerileri ile ilgili tanımlayıcı İstatistikler Tablo 1 de verilmiştir.

Tablo 1. Öğrencilerin Empati Becerisi ve Problem Çözme Becerileri İle Illgili Puanlart ve Tanımlayıcı Istatistikleri Gösteren Tablo.

\begin{tabular}{|c|c|c|c|c|c|}
\hline \multicolumn{7}{|c|}{ Tanımlayıcı İstatistikler } \\
\hline & $\mathrm{N}$ & Minimum & Maksimum & Ortalama & Standart Sapma \\
\hline Problem puan & 165 & 52 & 129 & 85,66061 & 14,0037 \\
\hline Empati puan & 165 & 68 & 146 & 116,4667 & 15,61368 \\
\hline
\end{tabular}

İki ölçeğe ilişkin puanlar arasındaki Korelasyon değerleri Tablo 2 de verilmiştir. Korelasyon değerlerinde istatistik açıdan önemlilik bulunamamıştır ( $(\mathrm{r}=0,099, \mathrm{p}>0,05)$.

Tablo 2. Öğrencilerin Empati Becerisi ve Problem Çözme Becerileri İle İlgili Puanları Arasındaki Korelasyon Değerlerini Gösteren Tablo.

\begin{tabular}{|c|c|c|c|}
\hline \multicolumn{4}{|c|}{ Korelasyonlar } \\
\hline & & Problem puan & Empati puan \\
\hline Problem puan & Pearson Korelasyonu & 1 & 0,099003 \\
\hline & Önemlilik (2- yönlü) & 0,208628 & \\
\hline & N & 165 & 163 \\
\hline Empati puan & Pearson Korelasyonu & 0,099003 & 1 \\
\hline & Önemlilik (2- yönlü) & 0,208628 & 165 \\
\hline & N & 163 & \\
\hline
\end{tabular}

İki ölçeğe ilişkin dört programa ait puanlar ve bu puanlara ait karşılaştırmalar Tablo 3 de verilmiştir. Problem çözme becerisi ve empatik becerilerde dört program arasında istatistiki olarak önemli farklılık olmadığı saptamıştır ( $>>0,05)$. 
ULUDAĞ ÜNIVERSITESI SAĞLIK HIZMETLERİ MESLEK YÜKSEKOKULU ÖĞRENCILERININ PROBLEM 15 ÇÖZME BECERLILLERİ İLE EMPATIK BECERILERININ KARŞILAȘTIRILMASI

Tablo 3. Öğrencilerin Empati Becerisi ve Problem Çözme Becerileri İle İlgili Puanlarl ve Bu Puanlara Ait Karşılaştırmaları Gösteren Tablo.

\begin{tabular}{|c|c|c|c|c|c|c|}
\hline \multicolumn{7}{|c|}{ ANOVA } \\
\hline & & Kareler Toplamı & S.D & Ortalama Kareleri & F & Onemlilik \\
\hline $\begin{array}{c}\text { Problem } \\
\text { puan }\end{array}$ & Gruplar Arası & 61,64894 & 3 & 20,54965 & 0,102432 & 0,958525 \\
\hline & Grup lçi & 32098,91 & 160 & 200,6182 & & \\
\hline & Toplam & 32160,55 & 163 & & & \\
\hline $\begin{array}{c}\text { Empati } \\
\text { puan }\end{array}$ & Gruplar Arası & 992,1416 & 3 & 330,7139 & 1,359715 & 0,257119 \\
\hline & Gruplçi & 38915,66 & 160 & 243,2229 & & \\
\hline & Toplam & 39907,8 & 163 & & & \\
\hline
\end{tabular}

Öğrencilerin empati becerisi ve problem çözme becerileri ile ilgili puanların cinsiyetlere göre farklı1ıkları Tablo 4 de gösterilmiştir. Cinsiyetler arası karşılaştırmada istatistiki olarak önemli farklılık bulunmamıştır ( $>0,05)$.

Tablo 4. Öğrencilerin Empati Becerisi ve Problem Çözme Becerileri ile Illgili Puanların Cinsiyetlere Göre Farklılıklarını Gösteren Tablo.

\begin{tabular}{|c|c|c|c|c|c|c|c|c|c|c|}
\hline \multicolumn{11}{|c|}{ Bağımsız Örnekler için T Testi } \\
\hline & & \multicolumn{2}{|c|}{$\begin{array}{l}\text { Levene'nin Varyans } \\
\text { Eşitliği Testi }\end{array}$} & \multicolumn{7}{|c|}{ T testi } \\
\hline & & \multirow{2}{*}{$F$} & \multirow{2}{*}{ Önemlilik } & \multirow{2}{*}{$\mathrm{t}$} & \multirow{2}{*}{ S.D. } & \multirow{2}{*}{$\begin{array}{l}\text { Önemlilik (2 } \\
\text { Yönlü) }\end{array}$} & \multirow{2}{*}{$\begin{array}{l}\text { Ortalamalar } \\
\text { Arası Farklılık }\end{array}$} & \multirow{2}{*}{$\begin{array}{l}\text { Farklılığın } \\
\text { Standart } \\
\text { Hatası }\end{array}$} & \multicolumn{2}{|c|}{$\begin{array}{l}\text { Farklııı̆ın \%95 Düzeyinde } \\
\text { Güven Aralığı }\end{array}$} \\
\hline & & & & & & & & & Alt Değer & Üst Değer \\
\hline $\begin{array}{c}\text { Problem } \\
\text { puan }\end{array}$ & $\begin{array}{c}\text { Varyanslar Eşit } \\
\text { kabul } \\
\text { Edildiğinde }\end{array}$ & 3,004136 & 0,084943 & $-1,78155$ & 163 & 0,076684 & $-5,14025$ & 2,885267 & $-10,8376$ & 0,557068 \\
\hline & $\begin{array}{l}\text { Varyansların } \\
\text { Eşit Olmadığı } \\
\text { Kabul } \\
\text { Edildiğinde }\end{array}$ & & & $-1,92303$ & 42,1 & 0,061253 & $-5,14025$ & 2,673001 & $-10,5341$ & 0,253577 \\
\hline $\begin{array}{l}\text { Empati } \\
\text { puan }\end{array}$ & $\begin{array}{c}\text { Varyanslar Eşit } \\
\text { kabul } \\
\text { Edildiğinde }\end{array}$ & 0,078912 & 0,779134 & 1,130904 & 163 & 0,259757 & 3,65902 & 3,235481 & $-2,72984$ & 10,04788 \\
\hline & $\begin{array}{l}\text { Varyansların } \\
\text { Eşit Olmadığı } \\
\text { Kabul } \\
\text { Edildiğinde }\end{array}$ & & & 1,136304 & 39,0 & 0,262759 & 3,65902 & 3,220105 & $-2,85413$ & 10,17217 \\
\hline
\end{tabular}

Öğrencilerin empati becerisi ve problem çözme becerileri ile ilgili puanların okudukları sınıflara göre farklılıkları Tablo 5 de gösterilmiştir. Birinci ve ikinci sınıflar arası karşılaştırmada istatistiki olarak önemli farklılık bulunmamıştır $(\mathrm{p}>0,05)$. 
Tablo 5. Öğrencilerin Empati Becerisi ve Problem Çözme Becerileri ile Ilgili Puanların Okudukları Sinfflara Göre Farklılıklarını Gösteren Tablo.

\begin{tabular}{|c|c|c|c|c|c|c|c|c|c|c|}
\hline \multicolumn{11}{|c|}{ Bağımsız Örnekler için T Testi } \\
\hline & & \multicolumn{2}{|c|}{$\begin{array}{l}\text { Levene'nin Varyans } \\
\text { Eşitliği Testi }\end{array}$} & \multicolumn{7}{|c|}{ T testi } \\
\hline & & \multirow{2}{*}{$\mathrm{F}$} & \multirow{2}{*}{ Önemlilik } & \multirow{2}{*}{$\mathrm{t}$} & \multirow{2}{*}{ S.D. } & \multirow[t]{2}{*}{$\begin{array}{l}\text { Önemlilik } \\
\text { (2 Yönlü) }\end{array}$} & \multirow[t]{2}{*}{$\begin{array}{c}\text { Ortalamalar } \\
\text { Arası Farklılık }\end{array}$} & \multirow[t]{2}{*}{$\begin{array}{c}\text { Farkllilığın } \\
\text { Standart } \\
\text { Hatası }\end{array}$} & \multicolumn{2}{|c|}{$\begin{array}{c}\text { Farklilığın \%95 Düzeyinde Güven } \\
\text { Aralığı }\end{array}$} \\
\hline & & & & & & & & & Alt Değer & Üst Değer \\
\hline \multirow[t]{2}{*}{$\begin{array}{c}\text { Problem } \\
\text { puan }\end{array}$} & $\begin{array}{c}\text { Varyanslar Eşit } \\
\text { kabul } \\
\text { Edildiğinde }\end{array}$ & 0,34125 & 0,559931 & 0,093462 & 160 & 0,925654 & 0,205277 & 2,196377 & $-4,13235$ & 4,542906 \\
\hline & $\begin{array}{c}\text { Varyansların } \\
\text { Eşit Olmadığı } \\
\text { Kabul } \\
\text { Edildiğinde }\end{array}$ & & & 0,093578 & 159,9 & 0,925561 & 0,205277 & 2,193637 & $-4,12694$ & 4,537493 \\
\hline \multirow[t]{2}{*}{$\begin{array}{c}\text { Empati } \\
\text { puan }\end{array}$} & $\begin{array}{c}\text { Varyanslar Eşit } \\
\text { kabul } \\
\text { Edildiğinde } \\
\end{array}$ & 0,050741 & 0,822067 & 0,169052 & 160 & 0,865969 & 0,414214 & 2,450216 & $-4,42472$ & 5,253148 \\
\hline & $\begin{array}{c}\text { Varyansların } \\
\text { Eşit Olmadı̆ı } \\
\text { Kabul } \\
\text { Edildiğinde }\end{array}$ & & & 0,168854 & 158,5 & 0,866127 & 0,414214 & 2,453089 & $-4,43074$ & 5,259168 \\
\hline
\end{tabular}

Öğrencilerin mezun oldukları lise türlerinin, yaşadıkları yerin, okulu tercih sırasının, meslek sevgisinin problem çözme becerileri ve empatik becerileri üzerine önemli bir etkisinin olmadığ belirlendi $(\mathrm{p}>0,05)$.

\section{Sonuç}

Problem çözme becerisine sahip olma ve empatik beceriler meslek yaşamında karşılaşılan sorunların çözümünde ve bilgi dünyasına uyum sürecinde anahtar unsurlardandır. Meslek yüksekokullarında verilen eğitimin, öğrencilerin PÇB ve EB üzerine olumlu katkı sağlaması, eğitimin kalitesi açısından önemli olacaktır. Yardımcı Sağlık Personeli yetiştiren her okuldaki öğrencilerin, her sınıfta PÇB ve EB'lerinin değerlendirilmesi, olumlu ve olumsuz etki eden faktörlerin belirlenmesi, öğretim elemanlarının kendi PÇB ve EB düzeylerinin araştırılması, Yardımcı Sağlık Personeli eğitimi almakta olan öğrencilere sistemli bir şekilde PÇB'ni ve EB'yi geliştirecek eğitim verilmesi ve bunun Yardımcı Sağlık Personeli eğitimi içinde kullanılmasının sağlanması (hem teorik hem uygulamalı şekilde),Yardımcı Sağlık Personeli öğrencilerinin PÇB ve EB ile akademik başarıları arasındaki ilişkinin araştırılması, Çalışan Yardımcı Sağlık Personeli PÇB ve EB'lerinin araştırılması verilen eğitimin ve yetişen sağlık personelinin kalitesinin yükseltilmesi açısından önem arz etmektedir. $\mathrm{Bu}$ konuda daha kapsamlı araştırmaların yapılması zorunludur.

\section{KAYNAKLAR}

1. YURTTAŞ, Afife YETKİN Ayşen ( 2003 ). Sağlık yüksekokulu öğrencilerinin empatik becerileri ile problem çözme becerilerinin karşılaştırılması, Atatürk Üniversitesi Hemşirelik Yüksekokulu Dergisi, Cilt: 6, Sayı:1

2. KELLECİ Meral, GÖLBAŞI Zehra (2004). Bir üniversite hastanesinde çalışan hemşirelerin problem çözme becerilerinin bazı değişkenler açısından incelenmesi, C.Ü. Hemşirelik Yüksekokulu Dergisi 2004, 8 (2) 